\title{
Study Area Geomorphology Manado
}

\author{
Rosita Treny Selvana Tewal* \\ geography Deparment \\ Faculty of Social Sciences, State \\ University of Manado \\ Manado, North Sulawesi \\ sevana.tewal@gmail.com
}

\author{
Helena Sri Sulastriningsih \\ Geography Department \\ Faculty of Social Sciences, State \\ University of Manado \\ Manado, North Sulawesi \\ hssulastri14@gmail.com
}

\author{
Jelly Robot \\ Geography Department \\ Faculty of Social Sciences, State \\ University of Manado \\ Manado, North Sulawesi \\ robotjelly08@gmail.com
}

\begin{abstract}
The problem in this research is the variety of topography, rock and rainfall conditions Manado City, all of which affect the condition of geomorphology and geomorphological processes in Manado Interest implemented this research is to assess the condition of geomorphology and geomorphological mapping the city of Manado. The method to be used include the analysis of maps, aerial photo interpretation, field observations to produce a map of geomorphology or landform geomorphology Manado based map will be obtained information about the land form the city of Manado, subsequently combined with the results of the field observations in order to obtain information about the process geomorphology happens in each landform in Manado City Research results show the city of Manado based Map Geomorphology in morphogenesis landform Manado City consists of three classifications namely landform origin process Fluvial, landform origin denudational process and landform Volcanic origin. Conditions morphometry and morphography Manado, as follows, morphometry indicated by the slope of $0 \%$ to> $15 \%$, and morphography include flood plains, alluvial plains, hills denudasional eroded medium, denudational hills eroded strong, slope amid volcano, the lower slopes of volcanoes and slopes foot volcano. Morfoassociation aspects occur because of the collaboration of various factors of the topography, constituent material, and precipitation. Tangible erosion, landslides and sedimentation collectible the three landforms in Manado City ie landforms Fluvial, denudational and landforms Volcanic, while morphochronology drawn from the condition of the material making up the rate of development varies from erosion / stadium young to old are seen from the rock material eroded further even the outcrop, as well as chunks of rock to the ground.
\end{abstract}

Keywords: Geomorphology, geomorphological processes, geomorphological map

\section{INTRODUCTION}

Manado City as one of the cities in Sulawesi are growing quite rapidly, and also serves as the capital city of North Sulawesi province. The rapid development seen in the establishment of shopping centers and complexhousing complexes, both elite housing areas to simple also their good hotels star hotels to the budget hotels. The development of the physical development of the city of Manado consequences trigger a new land clearing, cutting slope which would have an impact on landforms or geomorphological changes. Sutikno and Suprapto, 1997 said geomorphology is an assessment of landforms center of the focus is on nature / natural properties, geomorphic processes, genesis (origin of the constituent material) chronology, context with environmental and spatial aspects. Referring to these restrictions provide an understanding that the changes of landforms Manado should be reviewed from the aspect of nature, genesis, chronology and process and its relation to the environment and spatial aspects in this case how the impact of changes in geomorphology of the city of Manado on the environment and spatial aspects. On the other hand according to the data of rainfall Manado rainfall is high, $2869 \mathrm{~mm} /$ year (BMG 2014) where rainfall is one of the change agents form the earth's surface, in addition, wind, ice, waves and organic factors, proved the high rainfall Manado city and its surroundings are flash floods in 2014. In addition to the exogenous factors affecting the of geomorphological landforms Manado city,

An examination of the geology, Manado composed by rock unravel (unconsolidated), which material a young volcano as lava, bombs, lapilli and ash which as yet compact composing materials causing susceptible to erosion and landslide, terms of the topography of the city of Manado also varies from flat to steep, as well as in terms of hydrological Manado fed by rivers Molas, river Tikala or Kaliwang, river Sario, and river Malalayang, where these rivers if the overflow has influenced changes in the terrain or shape of the earth's surface or geomorphology in Manado.

The research problem is related to the landform Manado composed by rock unconsolidate, high rainfall, increased use of land for the physical development of the city of Manado, seismicity, land use and the presence of the rivers in the city of Manado, all of which contribute to changes in geomorphology Manado, so the research question formulated as follows: What is the condition of geomorphology Manado?

Objectives of this research is to produce a geomorphological map of Manado and description of morphogenesis, morphology, and morphoassociation morphochronology in Manado.

The benefits of this research as information about the condition of the geomorphology of Manado also for the development of geographical studies, especially the study of geomorphology or landform. 


\section{RESEARCH METHOD}

\section{A. Method}

To achieve the objectives, which examines the geomorphology of the city of Manado in order to produce a map landforms or geomorphological map is done by means of the following phases of procurement or material in the form of maps and images or photos are analyzed from the proportions and maps and photographs or imagery interpretation produces temporary geomorphological map.

Geomorphological map while as a reference for observation related to morphological aspects covered therein geological and morphological aspects in this case related to the state in terms of the study of landforms of the slope, the sensitivity of hills and valleys, as well as land use. Associated with morphogenesis in addition based on analysis of the geological map of Manado followed by observation against geomorphological processes that occur in the field and more emphasis on tangible exogenous processes of erosion processes, landslides and sedimentation. Aspects investigated the association between landforms relation to one another, carried out by observing the geomorphological processes in the area of research while analyzing the morphological aspects of geological maps, geomorphological processes as well as to the previous land use changes and soil conditions present.

Based on the mapping carried assessment, obtained information and a description of the geomorphological aspects of Manado City include morphological aspects monogenesis, mophochronology and morphoassociation. In addition it is also drafting geomorphological map of Manado City and Manado City geomorphology description.

\section{B. Objects and Research Subjects}

Research Object is the landform, while the research subject is the city of Manado

\section{C. stages Research}

Stages of this research was conducted as follows: Preparation: Survey and literature, map analysis and interpretation of aerial photographs, maps Making temporary geomorphology.

- Stages of the Job; observation / observation geomorphology Manado

- Post-course stages: Preparation of the final geomorfogi maps, geomorphological map description

- Report

\section{RESULTS AND DISCUSSION}

After the text edit has been completed, the paper is ready for the template. Duplicate the template file by using the Save As command, and use the naming convention prescribed by your conference for the name of your paper. In this newly created file, highlight all of the contents and import your prepared text file. You are now ready to style your paper; use the scroll-down window on the left of the MS Word Formatting toolbar.

\section{A. Location and Boundaries Research Areas}

The study area includes the District of Molas, Wenang, Sario, Tuminting, Tikala and District Malalayang. In astronomical research area is located between BT1 124o - 124o 10o 26 and 1o $521311 \mathrm{LU}$ and geographical region bordering the River Molas research in the north, east to the sub-district Mapanget, south to subdistrict Malalayang and the west bordering the bay of Manado.

\section{B. Climate}

Based on the calculation of rainfall data and temperature as an indicator of change, Manado classified on a very wet climate / Climate A by Schmid and Ferguson with a value of $\mathrm{Q}=1.89$.

\section{Geological conditions}

Geological conditions is one of the aspects studied in geomorphology of the area that shows the origin or genesis of landforms. In accordance Geological map Effendi Scale 1: 250000 (1976) study area is composed by rocks Alluvial (Qal) ie rocks that river sediment, tufa Tondano (QTV) is precipitated when the Pliocene and is estimated to come from the eruption of a great time of the formation of the caldera Tondano, units young volcanoes (Qx), younger volcanic rocks deposited on the quarter up to the present time, this unit tufa Tondano crushing unit. Based on the research results Kandoli 2004, Qal rocks found on both sides of the 5 rivers in the study area with a thickness of 2-3 meters, the five river in question is the Molas rivers, streams Tondano, kaliwang River, Rivers and River Malalayang Sario. Molas stream sediment and Maasing include Tumumpa village, Tondano river deposited include new tight urban village, Lawangirung, Karame, Wawonasa, Calaca, Istiqlal, Komo Luar, Pinaesaan and partly Tikala village Ares. Kaliwang stream sediment Perkamil terendaokan in the Village, Village Ranomuut, Dendengan In, New Tikala and partly Tikala village Ares. Sario river sediment covering the Village Karombaan, Ranotana, Pakowa, Wanea and villages Sario, Sario new City, Most Sario north and Sub Titiwungen. Malalayang include Malalayang River Village and Village Shoulder. Tondano Tuva unit includes the District of Molas, District Sario, and most of the District Malalayang. Young volcanic lithologies (Qx) deposited in the village of Malayang one and two village. These rocks can also be observed on the riverbank Malalayang.

\section{Hydrology conditions}

Hydrological conditions research areas include groundwater and surface water. Groundwater in the study area-extracted with dug wells with a depth of more hilltop 2meter deepened.

Surface water-related research region 5 existence permanently flowing river along the river year Molas, Tondano river, the river Tikala / Kaliwang, Sario river and 
Malalayang river. The existence of a river in terms of geomorphology study is very important because one of the agents that affect landform development process is running water / river because the water flow is one of energy other than wind erosion, glitzes, waves and organic factors.

\section{E. Land Use}

Land use affects the processes that occur on the surface of the land. Land use in accordance with the designation will provide maximum results compared with the use of land that is not in accordance with the designation. The land use study area includes settlements and other social facilities, moor, plantation and rainfed.

\section{F. Regional geomorphology}

Geomorphology aspect includes aspects of morphology, morphogenesis, morphocrology, morphoasociation.

1) AspekMorfologi research areas include morfografi Morphology and morphometry. Morfografi emphasis on the description of the landforms exist in the area of research that describes the genesis series of reliefs material. Morfografi related to the research area can be described as follows:

a) Alluvial plains (F1) formed on both sides of the river as a result of river sediment. The deposition process occurs when flooding that swelled rivers passing through the high valley of the river, sediment layered structure with low elevation with a slope of $0-3 \%$ constituent material of sand, loam, clay and dust, the process is the process of fluvial geomorphology with mild erosion

b) Floodplain (F2) periodically flood plain water inundated by overflowing rivers near or accumulation of free flow, flat topography with low elevation, slope $0-3 \%$

c) Denudational hills eroded medium (D2) In this landform erosion that developed mild to severe and the rock mass movement mild to severe. Relief bit rough, the slope of $3 \%$

d) Strong Denudational eroded hills (D3) In this landform is a process that works erosion and mass movement, many found a large rock outcrop, slope 3-13\%

e) Middle slopes (V4) Material constituent lava, bombs, lapilli and volcanic ash, erosion and gully erosion grooves and $\mathrm{V}$-shaped valley slope $8-50 \%$

f) Lower slopes of Volcano (V5) Zone transition middle and slopes down slopes and plains of the foot, there gully erosion and sheet with kembah $\mathrm{V}$ shape and slope $3-25 \%$ constituent material of lava, lapilli bombs and volcanic ash.

g) Volcano foot plateau (V7) landform is composed by lump material, Krakal and gravel, sand, dust, there is $\mathrm{n}$ da sheet erosion gully erosion, slope 1 $3 \%$.

2) Morphometry aspect morphometry aspect refers to the size of the morphology, this study examined the size aspect is focused on the slope. Based on the research results slope varies throughout the study area of o\% samapai greater than $15 \%$ dilaktegorikan three categories or the slope class $0-8 \%$ grade category I, slope $>8-15 \%$ class II and> $15 \%$ grade III. Overview slope in the area of research, it is shown through the maps of slope following:

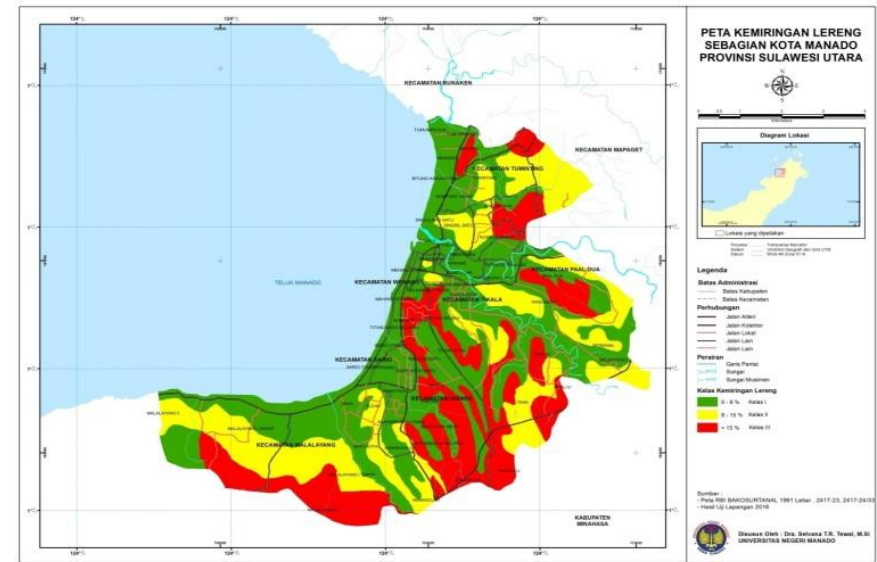

Fig. 1 Aspect Aspect morphogenesis Morphogenesis refers to the origin of landforms.

Landforms in the study areas are categorized as follows:

a) Originally landforms Fluvial Process (Its symbol F) landform origin fluvial processes are landforms caused by water flowing either converge or by free surface flow (over land flow). The existence of landforms origin fluvial processes related to the presence of five major rivers in the research area.

b) Originally landforms Denudational Process (D) These landforms are hilly areas and valleys, with a series of reliefs rough. In this landform erosion that developed mild to severe and the rock mass movement mild to severe. This landform research area found I Sub Malalayang, Molas and the District Wenang.in Malalayang and Wanea District.

c) Origin Volcanic landforms (V) is deposited landforms above Tufa Tondano, found in the village Malalayang constituent materials are lava, bombs, lapilli and volcanic ash.

Landform condition of the study area is shown through Geomorphology Map Manado Figure 2. 


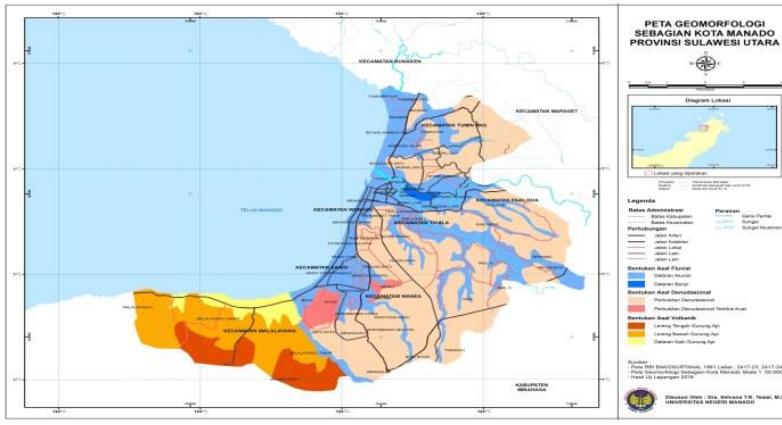

Figure 2.

3) Aspects morfokronologi an order landforms exist on the surface of the earth as a result of the process of geomorphology is based on the concept of Davis in Sutikno, Suprapto, 1997, explained that the development of landforms include the staging of young, older adults but in perkembanagan further categorization of this make it more concrete and factual categorized berdasrkan attrition rate is low, tinggi.Berdasarkan medium and the attrition rate in this psndsngsn, land development in the study area dilihatdari aspects uncategorized chronology at low to high erosion rates where indicated by the process of erosion of the mass movement and the presence of rock outcrops on the valley landforms denudasional and also many forms of $V$ and $U$ as well their regions or floodplain inundation in the city of Manado.

4) Aspect Aspect Morfoasosiasi morfoasosiasi appoint the links between landforms one with another landform. In this study clearly visible on the landforms in the city of Manado, geologically derived from material volcanoes, because the working process of geomorphology either in the form of erosion, landslides and sedimentation or sedimentation caused by the flow of the river, then in the development bentuklahannya produce three categories of landform volcanic, which is predominantly characterized by eruptive activity in this case related to the eruption well connected with the eruption of the Pliocene epoch Tondano caldera formation, as well as by young Lokon volcano activity.

The second is a landform landform origin denudational process is landforms characterized by a strong erosion work as well as the presence of mass movements such as landslides. Based on the research results Tewal, Sulastriningsih (2016) contained a landslide area in the city of Manado is Winagun Village, Citraland, Village Wanea, Village of Stone Town, Village Kombos, Village and Village Sumompo, Tingkulu. This condition is caused by the slope, also by heavy rainfall due to climate category according to Manado classified Smiht and Fergusson climate at very bases (A, with a value of $\mathrm{Q}$ $=1.89$ ). The third landform contained in Manado City is Fluvial landforms associated with the presence of 5 major river that flows in the city of Manado where the working of the river has resulted in the river sediments that support the occurrence of fluvial processes. In addition to the presence of the river, the city of Manado iklmi conditions also support the process of formation of fluvial landforms as seen from the weather conditions, almost every year in the rainy season floods, even in 2014 ago Manado city never experienced flooding catastrophic events. Based on this description seen that the development of landforms generally only occur by a geomorphological process but some enumerated factors and interrelated processes Manado city climate conditions also support the process of formation of fluvial landforms as seen from the weather conditions, almost every year in the rainy season floods, even in 2014 ago Manado city never experienced flash flooding catastrophic events. Based on this description seen that the development of landforms generally only occur by a process geomorphology but some enumerated factors and interrelated processes Manado city climate conditions also support the process of formation of fluvial landforms as seen from the weather conditions, almost every year in the rainy season floods, 2014 ago Manado city never experienced flash flooding catastrophic events. Based on this description seen that the development of landforms generally only occur by a process geomorphology but some enumerated factors and interrelated processes

\section{CONCLUSION}

\section{A. Conclusion}

Geomorphology Manado include morphological aspects such as flood plains, hills eroded moderate and strong, middle slope, lower slope and foot volcanic slope. Aspects morphometry indicated by the slope of $0 \%$ to $>$ $15 \%$, aspects of morphogenesis shown by landform origin of the fluvial process denudational and landform origin of the volcanic, and aspects morphoassociation indicated by the landslides, erosion and sedimentation as a combination of rainfall, slope and geomorphological processes. Changes in Manado natural landforms dominated by a process of erosion, sedimentation and landslides caused by the action of flowing water and topography, and also by human activity.

\section{B. Suggestion}

Manado City development associated with land use shows a study of the city of Manado geormorphology important to always do.

\section{REFERENCES}

[1] Effendi, 1976 applying the Geological Map Sheet 2416 -2417 Manado, Jakarta, Directorate of Geology Department of Mines RI

[2] TR Selvana Tewal, H. Sri Suastriningsih, 2016, Evaluation of Post-Disaster Avalanche Danger Level Floods 2014 In the city of Manado North Sulawesi Province. Peneitian institutions UNIMA

[3] TB Sontje Kandoli 2004 Suitability Evaluation of Land Settlement In the city of Manado, North Sulawesi, Thesis S2, Postgraduate UGM

[4] Sutikno, Suprapto, 1997, Basic Geomorphology, University of Gadjah Mada. 